\title{
Natural gaps associated with oxidative stress in Willisornis poecilinotus (Aves: Thamnophilidae) in a tropical forest
}

\author{
Andreza de Lourdes Souza GOMES ${ }^{1}$, Andrey Felipe Gomes GONÇALVES ${ }^{2 *}$, José Luiz Fernandes VIEIRA², \\ Maria Luiza Videiro MARCELIANO ${ }^{1}$, José Maria Cardoso da SILVA ${ }^{3}$ \\ 1 Museu Paraense Emílio Goeldi. Av. Perimetral, 1901- Terra Firme, CEP: 66077-830. Belém, Pará, Brazil. ansouzagomes@ig.com.br \\ 2 Universidade Federal do Pará . Rua Augusto Corrêa, 01- Guamá Campus Básico, CEP: 66075-110. Belém, Pará, Brazil. \\ ${ }^{3}$ Conservation International. 2011 Crystal Drive, Suite 500. 22202. Arlington, Estados Unidos. jsilva@conservation.org \\ * Corresponding author: andreybiologo@gmail.com
}

\section{ABSTRACT}

Natural disturbances in tropical forests modify the availability and quality of resources and alter the patterns of bird distribution. These environmental changes increase the metabolic rate and disrupt the redox balance promoting oxidative stress. This study aimed to compare the abundance of Willisornis poecilinotus between gaps and the understory of a forest with undisturbed canopy at Caxiuaná National Forest. The abundance was correlated with vegetation heights. The oxidative stress and the stress promoting factors were determined in both sites of sampling. We captured 81 specimens of W. poecilinotus. The number of captures was high in gaps. The specimens sampled at gaps showed high levels of oxidative stress. The biomarkers of oxidative stress were significantly correlated in gaps. The variability of oxidative stress and oxidative damage were explained only by site of sampling. These results suggest that gaps are stressors sites to W. poecilinotus, which probably can be due to an increase of metabolic rate to deal with new flight strategies of foraging and avoid predation

KEYWORDS: antioxidants, environmental disturbances, redox balance, lipid peroxidation.

\section{Clareiras naturais associadas ao estresse oxidativo em Willisornis poecilinotus (Aves: Thamnophilidae) em uma floresta tropical}

\section{RESUMO}

Os distúrbios naturais nas florestas tropicais contribuem para heterogeneidade do habitat, alterando os padrôes de distribuição das aves. Estas alteraçóes no ambiente elevam o metabolismo, promovendo distúrbios no balanço redox, e em consequência o estresse oxidativo. O objetivo deste estudo foi comparar a abundância de Willisornis poecilinotus entre clareiras e subbosque de dossel intacto associando-a a altura da vegetação na Floresta Nacional de Caxiuanã. A seguir, foi avaliado o estresse oxidativo e os fatores promotores de estresse foram determinados nos ambientes selecionados. Foram capturados 81 espécimes de $W$. poecilinotus. O número de capturas foi superior nas clareiras, quando comparado ao sub-bosque de dossel contínuo. Os espécimes capturados nas clareiras apresentaram índices de estresse oxidativo significativamente elevados. Foi observada correlação significativa entre os marcadores de estresse oxidativo nas clareiras. As variaçóes do biomarcador de dano oxidativo e do estresse oxidativo foram explicadas somente pelo sítio de amostragem. Estes resultados sugerem que as clareiras são sítios de estímulos estressores para W. poecilinotus o que provavelmente resulta da maior demanda metabólica para novas estratégias de forrageio e para evitar a predação.

PALAVRAS-CHAVE: antioxidantes, distúrbios ambientais, balanço redox, peroxidação de lipideos. 


\section{INTRODUCTION}

Natural disturbances in tropical forests alter availability and quality of resources, promoting substantial metabolic costs to birds, with consequent increase in the generation of oxidative compounds causing oxidative stress which is defined as the increase of production of oxidative compounds without the effort of compensatory antioxidant defenses, leading to an extensive oxidative damage to biomolecules, such as proteins, lipids, and nucleic acids (Beckman and Ames 1998; De Crommenacker et al. 2011).

Tree fall gap openings in the canopy, caused by the death of one or more trees, are the dominant form of natural disturbance in neo-tropical forests (Denslow and Hartshorn 1994). These sites represent a distinct microhabitat that differs from the understory of surrounding forest in the structure of vegetation, composition of species of plants, microclimatic conditions and abundance of resources. Leaf litter is usually abundant in gaps, as well as, high concentration of soil and litter invertebrates have been described in these areas. The gaps influence abundance and distribution of species of birds by maintaining the heterogeneity of the habitat and by changing the patterns of resource availability (Brokaw 1985; Denslow and Hastshorm 1994).

The gaps impose metabolic costs to birds, as new strategies of flight, both to avoid predators, as well as the foraging, which may be accompanied by increased generation of oxidative compounds (Swaddle et al. 1999; Larcombe et al. 2008). A similar pattern of physiological response to account for the oxidative damage has been reported for several species of birds. The redox balance in these vertebrates is maintained by a complex antioxidant system composed by endogenous compounds, as antioxidants enzymes, and exogenous ones, such as carotenoids, essential metals, bioflavonoid, and vitamins that delay or prevent the deleterious effects of oxidative compounds (Halliwell and Gutteridge 2007; Cohen et al. 2007; Cohen et al. 2009).

The relationship between natural disturbances and the physiological response of birds that ensures the redox balance was not assessed in the tropical forests. Willisornis poecilinotus may be a suitable model for evaluating the redox balance of resident birds in neo-tropical forests. It is one of the most common insectivorous birds in the understory of tropical forests of South America. The bird exhibits pronounced sexual dimorphism in plumage (Agne and Pacheco 2007). These birds are not aggressive and do not invade the territory of other specimens (Willis 1982).

The objectives of this study were to compare the abundance and oxidative stress of $W$. poecilinotus (Cabanis, 1847) between tree fall gaps and the understory of a forest with undisturbed canopy. The profile of vegetation was correlated with data from abundance to determine the height of foliage preferred by this species. The oxidative stress was quantified to assess if the sampling site (gap or forest) and sex are stressing stimuli for $W$. poecilinotus. As the changes in the structure of the habitat have been associated with oxidative stress in birds, we expected that tree fall gaps are sites of stressing stimuli for these birds.

\section{MATERIALS AND METHODS}

\section{Field work}

The study was carried out in 2010 and 2011 at Caxiuaná National Forest, Melgaço, Pará, Brazil (010 42’ 30”S; 51º 31' 45”W; $60 \mathrm{~m}$ a.s.l.), with about 220,000 ha. (Silva and Rosario 2008). Rainfall is concentrated during a six-month rainy season extended from January to June, with the dry season from July to December. Rain fall averages are 1,713 $\mathrm{mm}$ and $534 \mathrm{~mm}$ in rainy and dry seasons, respectively. Average monthly temperatures vary from $22^{\circ} \mathrm{C}$ to $26.2^{\circ} \mathrm{C}$. Terra-firme constitutes $85 \%$ of the Caxiuanã National Forest. The understory vegetation is dense with numerous species of the Sapotaceae, Lecythidaceae and Caesalpiniaceae families (Lisboa et al. 1997).

Two different understory forest habitat types were selected for sampling on the basis of physiognomies: natural tree fall gaps and undisturbed forest. We have selected 12 sites (six tree fall gaps and six forests), alongside 100-200 m. In each site, groups of ten mist nets were set at ground level. A gap is defined as "the ground area under a canopy opening extending to the bases of the surrounding canopy trees" (Runkle 1981). They were formed by one or more tree falls. Precise ages of gaps were unknown, but all of them were estimated to be about $2-3$ years old. The mean area of gaps was $201 \pm 43.73 \mathrm{~m}^{2}$ ranging from 158 to $250 \mathrm{~m}^{2}$ (Brokaw 1982; Brokaw 1985).

The birds were sampled by using mist nets, which allow the manipulation of specimens (Gosler 2004). They were sampled monthly from November, 2010 to October, 2011. The mist nets (2.6 m height, $12 \mathrm{~m}$ length, 36- $\mathrm{mm}$ mesh) were opened at dawn, checked every hour, and closed at $14 \mathrm{~h} 00 \mathrm{~min}$ or during heavy rain. Gap nets were placed at the edges of gaps rather than in the center to minimize net visibility. Birds were netted for 2 days each month in three undisturbed forests and three gaps simultaneously and the remaining in the next 2 days. A total of 23,040 mist net hours was accrued over the several seasons of study. The data for sex, molt and reproduction were registered.

Blood sample was collected in heparinized microhematocrit tubes by puncturing the brachial vein with a 26 gauge needle. An attempt was made to avoid taking more than $10 \%$ of the bird blood volume. Plasma was separated from cells after centrifugation at 2,000 $\mathrm{g}$ for $6 \mathrm{~min}$ and the samples were immediately analyzed (Wills 1966). All birds 
were banded and released in the vicinity of capture area. All fieldwork was conducted with the required authorization for capture, ringing and blood sampling of birds of the Instituto Chico Mendes de Conservação da Biodiversidade -ICMBio (nr 23343-1).

\section{Vegetation structure}

The foliage height profiles were determined in 99 gaps and 84 undisturbed forest sites according to Schemske and Brokaw (1981). The profiles were obtained by establishing two parallel transects one on each side of a net, situated $2 \mathrm{~m}$ from the net and equal in length to the sampled net. A 3-m pole $(2.0 \mathrm{~cm}$ diameter $)$ marked at $0.5-\mathrm{m}$ was placed vertically at each sample point. The presence or absence of foliage was recorded touching the pole within each height interval. For height intervals above $3 \mathrm{~m}$, we sighted along the pole and recorded the presence or absence of foliage along the sight line of the pole and estimated height intervals. Height intervals above the ground (in meters) were: $0-0 \mathrm{~F} 0,5 ; 0,5 \mathrm{~F} 1,0 ; 1,0$ $\mathrm{H} 2,0 ; 2,0 \mathrm{H} 3,0 ; 3,0 \mathrm{H} 4,0 ; 4,0 \mathrm{H} 6,0 ; 6,0 \mathrm{H} 8,0 ; 8,0 \mathrm{H} 10,0$; 10,0 H12,0; 12,0 H15,0; 15,0 H20,0 and > $20 \mathrm{~m}$ (Schemske and Brokaw 1981).

\section{Evaluation of oxidative stress}

To evaluate oxidative stress (OS), juveniles and specimens in molt or reproduction were excluded. Oxidative stress was determined as the ratio between oxidative damage and total antioxidant status. The former was evaluated by thiobarbituric acid reactive substances (TBARS) assay which has been used to estimate the products of lipid peroxidation, as malondialdehyde (MDA) (Cohen and Horak 2010, Costantini 2008). In this paper, we used the spectrophotometric determination of MDA based on its derivation with thiobarbituric acid (TBARS assay). Briefly, the lipoproteins are precipitated from the specimen by adding trichloroacetic acid. About $0.05 \mathrm{M}$ of $0.67 \%$ Thiobarbituric Acid (TBA) in $2 \mathrm{M}$ sodium sulphate are added to this precipitate and the coupling of lipid peroxide with TBA is carried out by heating in a boiling water bath for 30 minutes. The resulting chromogen is extracted in $\mathrm{n}$-butanol and the absorbance measured at $530 \mathrm{~nm}$. The TBARS of samples was expressed as n-moles of MDA per liter by using a calibration curve plotted against different amounts of 1,1,3,3-tetraethoxypropane (Isaksson et al. 2009).

Total antioxidant status (TAS) was evaluated by Trolox Equivalent Antioxidant Capacity (TEAC) assay according to Re et al. (1999). This assay reflects levels of circulating micro molecular antioxidants including uric acid, vitamin $\mathrm{C}$, vitamin $\mathrm{E}$ and carotenoids, but does not reflect the levels of enzymatic antioxidants or other macromolecules with antioxidant properties. The antioxidant status of samples was expressed as Trolox Equivalent Antioxidant Capacity (TEAC) in m-moles per liter, by using a calibration curve plotted against different amounts of Trolox (Cohen and Horak 2010).

\section{Statistical Analysis}

Data are reported as mean \pm standard deviation (SD). The normality of variables was evaluated by Lilliefors. The abundance of $W$. poecilinotus was compared between gaps and undisturbed forest sites by Chi-square. The foliage height profiles were compared between sites by ANOVA or KruskalWallis. The coefficient of correlation of Pearson or Spearman was used to correlate the abundance of specimens with foliage profiles. The levels of OS, TBARS and TAS were compared between sex and sites of sampling by two-way ANOVA. The coefficient of correlation of Pearson was used to determine the correlations between MDA and TAS in both sites. Student $t$ test was used to compare MDA, TAS and OS between sites. To determine the factors accounting for the variation in MDA, TAS and OS we have used generalized linear mixed models. The variables explanatory chosen were site of sampling (gap or undisturbed forest) and sex. Model selection was based on stepwise backward elimination of the non-significant terms in the order of their significance assessed by their Wald statistics. All eliminated terms were reintroduced to the final model to confirm their lack of contribution and to check how they affected the fit of the model. We used the normal error and the identity link function for modeling. Statistical analyses were performed with Statistica software package (Version 7.0, Stat Soft Inc. (2004), Tulsa, USA). Significance was accepted at $\mathrm{p}<0.05$.

\section{RESULTS}

We registered 81 specimens of $W$. poecilinotus (31 male and 50 female). The number of specimens captured in the gap was significantly high, when compared to the undisturbed forest (54 and 27, respectively; $\mathrm{p}<0.05$ ). The abundance of specimens in the gap was correlated with foliage height of 3 to 4 meters $(\mathrm{p}<0.05)$.

The levels of TBARS and OS were similar between the sex of specimens captured in gaps (TBARS $\mathrm{p}=0.92$; OS $\mathrm{p}=0.62$ ) and in undisturbed forest sites (TBARS $\mathrm{p}=0.5$; OS $\mathrm{p}=0.85$ ). However, the levels of TBARS were significantly high in male and female of specimens captured in the gaps $(\mathrm{p}<0.05)$, respectively, when compared to the undisturbed forest. In the gaps, OS was significantly high in male $(\mathrm{p}<0.05)$ and female $(p<0.05)$, when compared to the undisturbed forest, suggesting that the gaps may cause stressing stimuli to $W$. poecilinotus (Table 1). The levels of TAS were similar between sex and sites of sampling.

The levels of TAS and TBARS were significantly correlated in gaps $(p<0.05)$. However, this relationship was not significant in undisturbed forest $(\mathrm{p}>0.05)$. The variances of 
Table 1 - Levels of thiobarbituric acid reatives substances (TBARS), total antioxidant status (TAS) and oxidative stress (OS), expressed as mean (standard deviation, SD, in parenthesis), in male and female specimens of Willisornis poecilinotus sampled at gaps and undisturbed sites of Caxiuanã National Forest.

\begin{tabular}{lccccc}
\hline Site of sampling & $\mathrm{n}$ & Sex & $\begin{array}{c}\text { TBARS } \\
\text { nmoles } \\
\text { MDA L-1 }\end{array}$ & $\begin{array}{c}\text { TAS } \\
\mu \text { mol L}^{-1}\end{array}$ & $\begin{array}{c}\text { OS } \\
\text { (ratio TBARS/TAS) }\end{array}$ \\
\hline Gap & 15 & Male & $0.53(0.22)^{\mathrm{Aa}}$ & $0.35(0.11)^{\mathrm{Aa}}$ & $1.43(0.35)^{\mathrm{Aa}}$ \\
\hline Undisturbed forest & 15 & Female & $0.54(0.27)^{\mathrm{Aa}}$ & $0.46(0.28)^{\mathrm{Aa}}$ & $1.31(0.47)^{\mathrm{Aa}}$ \\
& 13 & Male & $0.33(0.06)^{\mathrm{Bb}}$ & $0.35(0.04)^{\mathrm{Aa}}$ & $0.95(0.31)^{\mathrm{Bb}}$ \\
\hline
\end{tabular}

Means followed by the same capital letters between sampling sites and the same lower case letter between sexes do not differ at $p<0.05$ ( two-way ANOVA for sampling sites and sexes)

TBARS $(\mathrm{p}<0.005)$ and $O S(\mathrm{p}<0.05)$ were explained by the site of sampling. However, the variance of TAS was not explained by the site of sampling $(p>0.05)$ (Figure 1$)$.
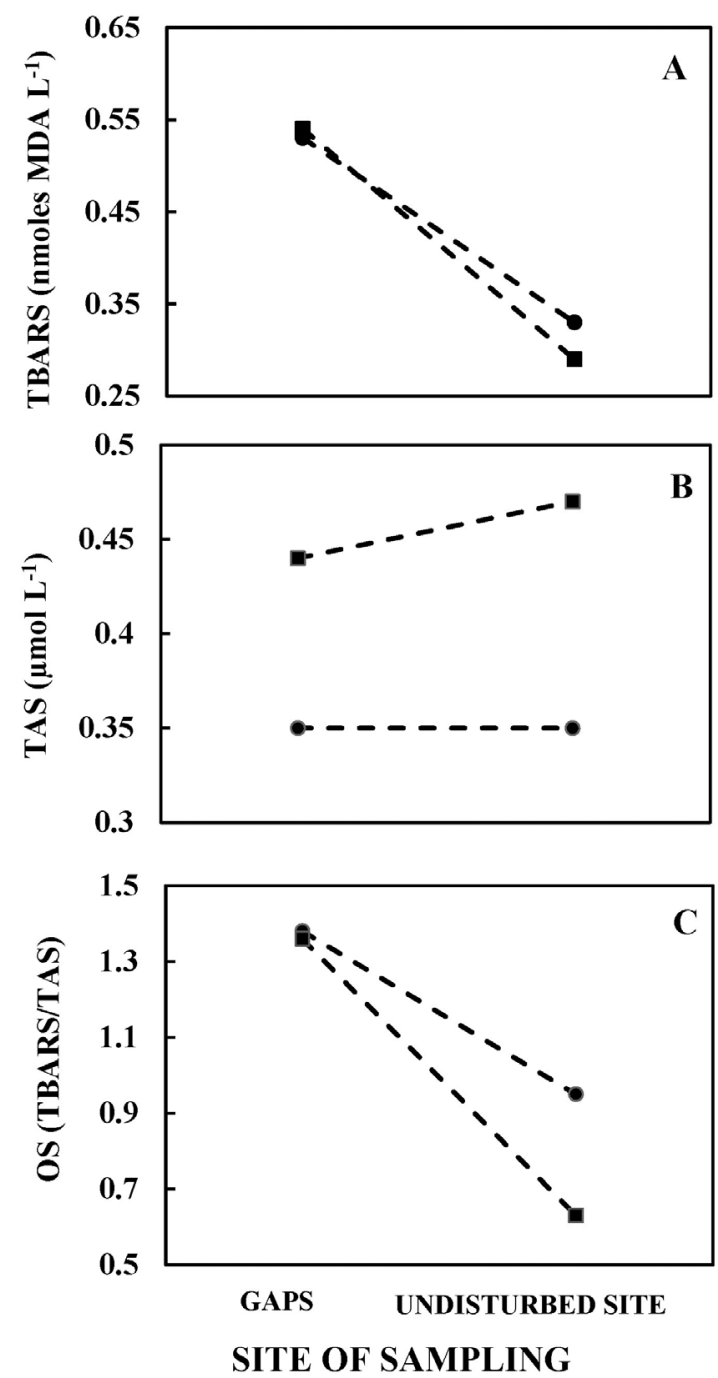

Figure 1- Thiobarbituric acid reatives substances $(A)$, in nmoles MDA L-1 , total antioxidant status (B), in $\mu \mathrm{mol} \mathrm{L}^{-1}$ and oxidative stress (C) in male (---•---) and female(-----) specimens of Willisornis poecilinotus sampled at gaps and undisturbed sites of Caxiuanã National Forest

\section{DISCUSSION}

The changes in structure and composition of vegetation have a significant role in the distribution of birds in Neotropical Forests (Brokaw 1982; 1985). The specimens of W. poecilinotus were captured mainly in gaps. Birds may be attracted to gaps due to the presence of more 'edge' habitats; more foliage at net level, which can be used for protection against predators; increased availability of perches; and higher primary productivity of these sites (Schemske and Brokaw 1981). In fact, Willis (1982) and Cintra and Cancelli (2008) reported that the distribution of this species occurs mainly in open canopy and in sites with leaf litter.

The importance of the availability of food in determining the habitat used by birds has been evaluated in several ecological studies (Cody, 1985). In forest sites, the habitat is selected according to the availability of resources (Harrison 1962), which can be high in gaps because of the high primary productivity resulting from microclimatic changes in these sites (Blake and Hopes 1986). Willisornis poecilinotus and other insectivorous birds may be attracted to the gaps because insects and other invertebrates are more abundant in gaps than in undisturbed forest sites, given that the gaps support relatively high proportion of foliage palatable to the herbivorous invertebrates, which may explain the correlation between the abundance of specimens and the foliage of low height in gaps. The avian prey selection is influenced by prey availability, including proximity, detectability, acceptance, and ability to successfully capture a potential prey (Wolda 1990; Willis 1982).

The changes in the structure of the habitat have been associated with increased oxidative stress, resulting from changes in the availability and quality of resources (de Crommenacker et al. 2011). In this paper, the oxidative stress was higher in specimens captured in gaps, indicating that these sites are stressing stimuli for $W$. poecilinotus. There are several microclimatic changes in gaps newly formed, such as light influx, humidity, and temperature, which increases availability of resources, and can entail metabolic costs to birds, as new strategies of flight, both to avoid predation (Schliemann and 
Bockheim 2011), as to maximizing foraging in an area of high availability of resources (Blake and Hoppes 1986). Probably, the high level of TBARS was responsible for oxidative stress in gaps. In fact, oxidative stress has been associated with both the effort of flight, as reported by Columba livia (Costantini et al. 2008) and by Melopsittacus undulatus (Larcombe et al. 2008), as the increase in consumption of food.

The oxidative stress was similar between male and female specimens. Some behavioral characteristics of this species, such as the absence of elaborate courtship by males (Willis 1982), and the investment in offspring by both parents can entail a similar allocation of resources to reproduction and self-maintenance between genders (Wiersma et al. 2004).

The antioxidant compounds maintain the redox balance (Cohen et al. 2009). In this study, the levels of TAS were correlated with the TBARS only in gap, suggesting that these sites may provide additional sources of antioxidants to account for the increase in TBARS. In fact, the gaps have been termed nutrient "hot spots" because they have high levels of nutrients resulting from decomposition and mineralization of organic matter (Mladenoff 1987, Schliemann and Bockheim 2011), which promotes significant increase of biomass of invertebrates, such as lepidopterans, which has been considered an important source of food for insectivorous birds, as well, the larvae has high antioxidant capacity (Richards and Coleys, 2007; Eeva et al. 2010).

\section{CONCLUSION}

The tree fall gaps may constitute specific habitat for some species of birds living in understory of tropical forests. The specimens of $W$. poecilinotus were distributed mainly in gaps, probably due to the concentration of resources and availability of perches. These sites promote stressing stimuli leading to oxidative stress in this species, probably due to an additional physical effort resulting from new strategies of flight, both for avoiding predators, as for maximizing the foraging, which increases oxidative metabolism. The oxidative stress was similar between males and females, probably due to the social behavior of this species, as the absence of elaborate courtship and the investment in nestlings by both parents.

\section{ACKNOWLEDGMENTS}

The authors would like to thank the Conselho Nacional de Desenvolvimento Científico e Tecnológico-CNPq, including the scholarship to the first author (114678/2009-0)

\section{REFERENCES}

Agne, C.E.; Pacheco, J.F. 2007. A homonymy in Thamnophilidae: a new name for Dichropogon Chubb. Revista Brasileira de Ornitologia, 15: 484-485.
Beckman, K.B.; Ames, B.N. 1998. The free radical theory of aging matures. Physiological Reviews, 78: 547-581.

Blake, J.G.H.; Hoppes, W.G. 1986. Influence of resource abundance on use of tree-fall gaps by birds in an isolated woodlot. The $A u k$, 103: 328-340.

Brokaw, N. 1982. The definition of treefall gap and its effect on measures of forest dynamics. Biotropica, 14: 158-160.

Brokaw, N.V.L. 1985. Gap-phase regeneration in a tropical forest. Ecology, 66: 682-687.

Cintra, R.; Cancelli, J. 2008. Effects of forest heterogeneity on occurrence and abundance of the scale-backed antbird, Hylophylax poecilinotus (Aves:Thamnophilidae), in the amazon forest. Revista Brasileira de Zoologia, 25: 630-639.

Cody, M. L. 1985. Habitat selection in birds. Academic Press, New York, New York, USA.

Cohen, A.; Klasing, K.; Ricklefs, R. 2007. Measuring circulating antioxidants in wild birds. Comparative Biochemistry Physiology B, 147: 110- 121 .

Cohen, A.A.; McGraw K.J.; Robinson, W.D. 2009. Serum antioxidants levels in wild birds vary in relation to diet, season, life history strategy, and species. Oecologia, 161: 673-683.

Cohen, A.A.; Horak, P. 2010. The Ecology of Antioxidants \& oxidative stress in animals- How to measure oxidative stress in an ecological context: methodological and statistical issues. Functional Ecology, 24: 960-970.

Constantini, D. 2008. Oxidative stress in ecology and evolution: lessons from avian studies. Ecology Letters, 11: 1238-1251.

Costantini, D.; Dell Ariccia, G.; Lipp, H.P. 2008. Long flights and age affect oxidative status of homing pigeons (Columba livia). Journal of Experimental Biology, 211: 377-381.

Crommenacker de, J.V.; Koumdeur, J.; Burke, T.; Richardson, D.S. 2011. Spatio-temporal variation in territory quality and oxidative status: a natural experiment in the Seychelles warbler (Acrocephalus sechellensis). Journal of Animal Ecology, 80: 668-680.

Denslow, J.S.; Hartshorn, G.S. 1994. Tree-fall Gap Environments and Forest Dynamics Processes. In: Mcdade, L.A.; Bawa, K.S.; Hespenheide, H.A.; Hartshorn, G.S. La Selva: Ecology and Natural History of a Neotropical Rain Forest. University of Chicago Press, Chicago, p.120-127.

Eeva, T.; Helle, S.; Salminen, J.P.; Hakkarainen, H. 2010. Carotenoid composition of invertebrates consumed by two insectivorous bird species. Journal of Chemical Ecology, 36: 608-613.

Gosler, A. 2004. Birds in the hand. In: Sutherland, W.J.; Newton, I.; Green, R.E. Birds ecology and conservation: a handbook of techniques. Oxford University Press, New York, p. 85-118.

Halliwell, B.; Gutterridge, J. 2007. Free Radicals in Biology and Medicine. Oxford University Press, Oxford UK. 266p.

Harrison, J.L. 1962. The distribution of feeding habits among animals in a Tropical Rain forest. Journal of Animal Ecology, 31: 53-63.

Isaksson, C.; Sturve, J.; Almroth, B.C.; Andersson, S. 2009. The impact of urban environment on oxidative damage (TBARS) 
and antioxidant systems in lungs and liver of great tits, Parus major. Environmental Research, 109: 46-50.

Larcombe, S.D.; Tregaskes, C.A.; Coffey, J.S.; Stevenson, A.E.; Alexander, L.; Arnold, K.E. 2008. The effects of short-term antioxidant supplementation on oxidative stress and flight performance in adult budgerigars Melopsittacus undulates. Journal of Experimental Biology, 211: 2859-2864.

Lisboa, P.L.B.; Silva, A.S.L.; Almeida, S.S. 1997. Floristica e estrutura dos ambientes. In: Lisboa, P.L.B. (Org.). Caxiuanã, Museu Paraense Emílio Goeldi, Belém, p. 163-194.

Mladenoff, D.J. 1987. Dynamics of nitrogen mineralization and nitrification in Hemlock and Hardwood Treefall Gaps. Ecology, 68:1171-1180.

Richards L.A.; Coley, P.D. 2007. Seasonal and habitat differences affect the impact of food and predation on herbivores: a comparison between gaps and understory of a tropical forest. Oikos, 116: 31-40.

Runkle, J.R. 1981. Gap regeneration in some old-growth forests of the eastern United States. Ecology, 62: 1041-1051.

Schemske, D.W.; Brokaw, N. 1981. Treefalls and the distribution of understory birds in a tropical forest. Ecology, 62: 938-945.
Schliemann, S.A.; Bockheim, J.G. 2011. Methods for studying treefall gaps: A review. Forest Ecology and Management, 261: 1143-1151.

Silva, M.R.P.; Rosário, S.M. 2008. Licófitas e Monilófitas (Pteridophyta) da Floresta Nacional de Caxiuaná, estado do Pará, Brasil: chave para as famílias e as espécies de Aspleniaceae e Blechnaceae. Boletim do Museu Paraense Emílio Goeldi. Ciências Naturais, 3: 151-163.

Swaddle, J.P.; Williams, E.V.; Rayner, J.M.V. 1999. The effect of simulated flight feather moult on escape take-off performance in starlings. Journal Avian Biology, 30: 351-358.

Wiersma, P.; Selman, C.; Speakman, J.R.; Verhulst, S. 2004. Birds sacrifice oxidative protection for reproduction. Proceedings of the Royal Society B, 271: 360-363.

Willis, E.D. 1966. Mechanism of lipid peroxide formation in animal tissues. Biochemical Journal, 99: 667-676.

Willis, E.O. 1982. The behavior of scale-backed antbirds. Wilson Bulletin, 94: 447-462.

Wolda, H. 1990. Food availability for an insectivore and how to measure it. Studies in Avian Biology, 13: 38-43.

Recebido em 30/01/2013

Aceito em 29/08/2013 